\title{
The impact of geographic market definition on the stringency of hospital merger control in Germany and the Netherlands
}

\author{
MARCO VARKEVISSER* \\ Associate Professor of Health Economics, Institute of Health Policy \& Management (iBMG), Erasmus University \\ Rotterdam, The Netherlands \\ FREDERIK T. SCHUT \\ Professor of Health Economics, Institute of Health Policy \& Management (iBMG), Erasmus University Rotterdam, \\ The Netherlands
}

\begin{abstract}
In markets where hospitals are expected to compete, preventive merger control aims to prohibit anticompetitive mergers. In the hospital industry, however, the standard method for defining the relevant market (SSNIP) is difficult to apply and alternative approaches have proven inaccurate. Experiences from the United States show that courts, by identifying overly broad geographic markets, have underestimated the anticompetitive effects of hospital mergers. We examine how geographic hospital markets are defined in Germany and the Netherlands where market-oriented reforms have created room for hospital competition. For each country, we discuss a landmark case where definition of the geographic market played a decisive role. Our findings indicate that defining geographic hospital markets in both countries is less complicated than in the United States, where antitrust analysis must take managed care organisations into account. We also find that different methods result in much more stringent hospital merger control in Germany than in the Netherlands. Given the uncertainties in defining hospital markets, the German competition authority seems to be inclined to avoid the risk of being too permissive; the opposite holds for the Dutch competition authority. We argue that for society the costs of being too permissive with regard to hospital mergers may be larger than the costs of being too stringent.
\end{abstract}

\section{Introduction}

Market-oriented healthcare reforms have in recent years created hospital competition in both Germany and in the Netherlands (Lisac et al., 2010; Schut and van de Ven, 2011). ${ }^{1}$ For such competition to be effective, insurers and patients

\footnotetext{
*Correspondence to: Professor Marco Varkevisser, Institute of Health Policy \& Management (iBMG), Erasmus University Rotterdam, Room J8-03, P.O. Box 1738, Rotterdam 3000, The Netherlands. Email: varkevisser@bmg.eur.nl

1 A detailed description of the healthcare systems in both countries is beyond the scope of this paper. Country summaries for Germany and the Netherlands can be found in Commonwealth Fund (2010).
} 
must be able to choose from a sufficient number of alternative providers. Competitive pressures, however, generally provoke consolidation (mergers) of healthcare providers, including hospitals. To safeguard competition, both German and Dutch hospital merger proposals are subject to antitrust law. The common objective of preventive merger control is to protect consumer welfare by prohibiting anticompetitive mergers. ${ }^{2}$ Defining the relevant geographic market is necessary to this process because antitrust authorities typically use market shares to make inferences about the likely effects of mergers. Although appropriate market definition is challenging in any industry, it is particularly so in the hospital industry. In general, antitrust enforcement agencies use the 'Small but Significant Non-transitory Increase in Price' (SSNIP) test to define the relevant market, ${ }^{3}$ which is difficult to implement in hospital markets for at least two reasons. First, prices for most hospital services are regulated. A hospital's quality elasticity of demand rather than its price elasticity is then of primary interest. Second, in (sub)markets where prices are not regulated, ${ }^{4}$ the necessary data for estimating hospitals' price elasticities are most often unavailable (Capps et al., 2002). Actual prices negotiated between hospitals and insurers are not readily available and even if these prices are available to antitrust agencies as part of their merger review, they do not represent the costs faced by patients. As the vast bulk of hospital services is covered by health insurance, hospitals are largely reimbursed by third-party payers; the patient, therefore, has a price elasticity close or equal to zero. Because of the difficulty of applying the SSNIP test in hospital markets, geographic market definition has historically relied heavily upon two alternative, less formal approaches: the Elzinga-Hogarty $(\mathrm{E}-\mathrm{H})$ test and critical loss analysis.

In this article, we examine the role of geographic market definition in hospital merger control. Using evidence from the United States, we explain why geographic

2 Courts and antitrust enforcement agencies in both the United States and Europe tend to use a consumer welfare standard (Motta, 2004: 19) for mergers. Recent papers, however, have discussed the proper objective of competition policy (e.g. Heyer, 2006; Carlton, 2007; Pittman, 2007). Although economists generally prefer total welfare, an important argument in favour of the consumer welfare standard is that it simplifies decisions in merger cases. That is, the use of a total welfare standard entails a difficult exercise in quantifying the changes in consumer and producer surplus to assess net welfare effects. In addition, horizontal mergers typically result in welfare transfers from consumers to producers that are likely to be quite regressive.

3 The SSNIP test begins by positing a narrowly defined market (e.g. one particular zip code) and asking whether a hypothetical monopolist of all firms and products in the posited geographic market could profitably implement a SSNIP. If the monopolist cannot do so, then the proposed market is too narrow and neighbouring zip codes should be included. The procedure is repeated until the answer is affirmative.

4 Since 2005, in the Dutch healthcare system, hospitals and health insurers are allowed to freely negotiate prices for part of the hospital services. Initially, this part was limited to $10 \%$ of total hospital expenditure, but the room for price negotiations was gradually expanded to $34 \%$ in 2011 and $70 \%$ in 2012. The prices of the rest of the hospital services are regulated. To prevent a hospital from setting an extraordinarily high price for the non-regulated services, insurers are allowed to selectively contract with hospitals or channel patients to hospitals with which favourable contracts are negotiated. 
market definition can be seen as the Achilles' heel of hospital merger control. We then focus on hospital merger control in Germany and the Netherlands, discussing a landmark case for each where definition of the relevant geographic market played a decisive role. ${ }^{5}$

\section{Geographic market definition: Achilles' heel of hospital merger control}

No country has more experience with hospital merger enforcement than the United States. After the first hospital merger was challenged in 1981, the Department of Justice (DOJ) and Federal Trade Commission (FTC) initially had considerable success litigating hospital merger cases. ${ }^{6}$ From 1989 to 2001, however, the federal antitrust agencies were defeated in all but one case brought to court (Gaynor and Vogt, 2000; Ashenfelter et al., 2011). ${ }^{7}$ Most were lost because the court identified highly expansive geographic markets that resulted in low post-merger concentration levels. ${ }^{8}$ Supported by empirical evidence on the anticompetitive effects of consummated hospital mergers (e.g. Vita and Sacher, 2001; Simpson, 2003), the courts' reasoning in these cases was widely criticised (e.g. Greaney, 2002; Conners, 2003; Richman, 2007). Most importantly, by accepting the E-H test or critical loss analysis to define the relevant geographic market, courts systematically underestimated the potential anticompetitive effects. Both approaches have proven inaccurate. Their most important shortcomings are summarised below. ${ }^{9}$

5 Within the European Union (EU), decisions on proposed hospital mergers are generally made by national antitrust enforcement agencies. Hospital mergers with an impact beyond the national borders are rare. In 2007, the European Commission (EC) reviewed a proposal under which two providers of investment management [UK's APW (Apax Partners Worldwide LLP) and France's APSA (Apax Partners SA)] and a Jersey-based private equity firm (Nordic Capital) would acquire joint control over Capio, a Swedish healthcare provider and owner of private hospitals, diagnostic centres and private psychiatric hospitals in a wide range of EU member states, including the United Kingdom, where APW already controlled a healthcare service provider. Using a separate product market for acute general hospital services provided by private hospitals, the EC concluded that the merger would raise serious competition concerns in the United Kingdom. As the EC argued that most patients do not travel far for treatment, geographic hospital markets were defined as local. The proposal was therefore approved, conditional to the divestiture of Capio's UK-based private acute general hospitals, its independent sector treatment centres outsourcing business and specialist eye hospital (EC, 2007).

6 The FTC and DOJ decide between themselves which agency will be responsible for the merger assessment.

7 In this context, 'court' means court or administrative law judge (ALJ) or full FTC; different cases are decided by different entities. If the FTC seeks a temporary injunction to block a merger pending trial, it will do so in federal district court. The ensuing trial, if it occurs, would be held before an ALJ, which decides the legality of the transaction. The ALJ's decision can be appealed to the full five-member FTC and ultimately the Supreme Court. In contrast, if the DOJ is responsible for reviewing the merger, the legality of the transaction is litigated in federal district court. A decision at that stage may be appealed to the circuit court and ultimately the Supreme Court.

8 The additional two cases were lost (at least in part) because the court ruled that the non-profit nature of the merging hospitals made the exercise of post-merger market power unlikely (Ashenfelter et al., 2011).

9 See for a more detailed discussion of both methods Varkevisser et al. (2008). 


\section{$2.1 \mathrm{E}-\mathrm{H}$ test}

The E-H test is easy to apply and uses commonly available patient flow data. It begins with a narrowly defined market and then expands the boundary until threshold conditions are met for both imports ['little in from outside' (LIFO)] and exports ['little out from inside' (LOFI)] of hospital services. ${ }^{10}$ In various court cases, the analysis has focussed on identifying geographic areas such that both statistics are either below 25\% ('weak market') or 10\% ('strong market'). The central problem underlying the E-H test is the 'silent majority fallacy' (Capps et al., 2002): the presence of travelling patients who import and export hospital services does not necessarily discipline hospitals from exercising market power over the silent majority of non-travelling patients. In other words, in markets with heterogeneous tastes for different services, the presence of some travelling patients with one set of needs does not necessarily restrain the pricing of services to non-travelling patients with different needs. Suppose that $25 \%$ of all patients in an area travel significant distances to receive care. This does not in any way indicate that the remaining $75 \%$ would be willing to similarly travel in response to a price increase - the assumption implicit in the E-H test. Hence, price increases are certainly feasible even in the presence of significant patient outflows. One might argue that use of the $\mathrm{E}-\mathrm{H}$ test would be less problematic if disaggregated clusters of hospital services that are close substitutes were analysed. However, this would only solve part of the problem, as it incorrectly assumes that the only reason the 'silent majority fallacy' exists is that patients' propensity to travel varies across types of hospital care. Other reasons the propensity to travel varies include, for example, unobserved personal preferences. Selecting a non-arbitrary way to aggregate the results of disaggregated, hospital service-level E-H analyses is also problematic. In a recent antitrust complaint involving a merged hospital (Box 1), both the FTC and the defendants agreed that applying the E-H test to define the relevant geographic market would be inappropriate (Elzinga and Swisher, 2011).

\subsection{Critical loss analysis}

Critical loss analysis involves three consecutive steps. The first is to compute the hospitals' contribution margins, defined as price minus average variable costs. The contribution margin is used in step two to identify the percentage of patients hospitals could lose before a small price increase $-5 \%$ is typical becomes unprofitable: this is the critical loss. The final step is to analyse whether the actual loss of patients would exceed the critical loss if all hospitals in the proposed market implemented a small but significant non-transitory price increase. If so, then the price increase would be unprofitable, indicating that the

10 When a patient from outside an area receives care from a hospital inside that area then that is an inflow of a patient but an export of hospital services. When a patient from inside an area receives care from a hospital outside that area then that is an outflow of a patient but an import of hospital services. 
Box 1. Federal Trade Commission (FTC) vs Evanston Northwestern Healthcare Corporation (ENH)

In February 2004, the FTC issued an antitrust complaint against ENH - a health system on Lake Michigan's north shore close to Chicago, Illinois. The FTC alleged that following the acquisition of the nearby Highland Park Hospital in January 2000, ENH was able to raise its prices far above comparable hospitals as a result of the transaction. When seeking a remedy to restore competition, the FTC's complaint contemplated a divestiture of the acquired hospital (FTC, 2004). In his initial decision, the Administrative Law Judge (ALJ) ordered this contemplated relief (FTC, 2005). Despite the criticism of some legal experts (e.g. Harris and Argue, 2006; Campbell, 2007), on appeal, this decision was confirmed by the full FTC. However, as much time had already elapsed after the merger, rather than divestiture, it ordered ENH to establish two separate and independent negotiating teams to allow health insurers to negotiate separately again with ENH and its former competitor Highland Park Hospital (FTC, 2007). In 2008, ENH accepted this remedy.

In contrast to previous hospital merger cases in the United States, in the Evanston case both the ALJ and the FTC concluded that the relevant geographic market was rather small. The ALJ's decision contained some interesting observations on defining geographic hospital markets. First, the Elzinga-Hogarty test, given its methodological shortcomings, was deemed 'not appropriate' for defining geographic hospital markets. Second, courts do not compel 'scientific precision', but any hospital market should be 'well-defined' and correspond to the 'commercial realities' of the hospital industry. Third, determination of the geographic market must be based on a dynamic 'forward looking' analysis, which considers where consumers have gone in the past for hospital services, as well as their future 'practical alternatives'. Fourth, in a managed care setting a key issue in determining the geographic market is identifying the hospitals that managed care organisations need in their provider networks to establish viable, competitive networks. On appeal the full FTC agreed with ENH that the ALJ did not address the central issue in defining geographic markets; that is, over what geographic region could a hypothetical monopolist impose a Small but Significant Nontransitory Increase in Price? However, as the consummated merger enabled ENH to raise prices substantially through a unilateral exercise of market power, it was concluded that the geographic area of the merged hospitals constituted a welldefined geographic market from an antitrust perspective.

hypothetical geographic market is too narrow and should be expanded to include more hospitals. The expected actual loss of patients is most commonly assessed using the concept of contestable zip codes. That is, all patients currently choosing a hospital within the proposed market but living in an area where 
many other patients (e.g. $50 \%$ or more) select hospitals outside the proposed market would switch to those outside hospitals in response to a price increase. Under this assumption, critical loss analysis also suffers from the 'silent majority fallacy'. Danger and Frech (2001) detail an important methodological shortcoming of critical loss analysis: market definition via this approach is highly sensitive to the initial degree of market power. If price is already at the monopoly level, then any further increase in price will by definition result in lower profits. In such a situation, critical loss analysis incorrectly leads to an overly broad market.

\section{Hospital merger control in Germany}

\subsection{Act against Restraints of Competition}

The 1958 Act against Restraints of Competition [Gesetz gegen Wettbewerbsbeschränkungen (GWB)] assigned the task of protecting competition at the national level in Germany to the Federal Cartel Office [Bundeskartellamt (BKA)]. A 1993 amendment introduced a procedure for preventive merger control in the GWB, which has been enforced relatively strictly, leading to a considerable number of merger prohibitions, proposal modifications and dismissals (Motta, 2004: 11). A main principle behind competition policy in Germany is to protect the economic freedom of competitors. A merger will therefore be prohibited if it is "expected to create or strengthen a dominant position", unless it "will also lead to improvements of the conditions of competition and that these improvements will outweigh the disadvantages of dominance" (Section 36.1). According to the GWB, a firm is dominant when in a properly defined market it (i) has no competitors, (ii) is not exposed to substantial competition or (iii) has a paramount market position relative to its competitors (Section 19.2). To assess a firm's market position, several factors should be taken into account: its market share, its financial power, any legal or factual barriers to market entry by other firms, actual or potential competition by firms and the ability of the opposite market side to resort to other firms.

The BKA's preventive merger control applies only to mergers whose aggregate global sales would exceed $€ 500$ million, with at least one firm realising $€ 25$ million in Germany. Mergers subject to control must subject themselves to examination by the BKA whose preliminary review leads to a more substantive examination if necessary. The BKA decides whether a merger is cleared, prohibited or cleared conditionally. If cleared, the parties must inform the BKA upon its consummation. Although the notification threshold is rather high, that it has resulted in an overly permissive antitrust enforcement policy is unlikely; so far mergers between German hospitals have typically involved the acquisition of public hospitals by large private hospital chains. It is important to recognise, however, that mergers between small independent hospitals may not be subject to the BKA's merger control, even though they may substantially reduce competition at the local or regional level. 
Impact of geographic market definition on hospital merger control 369

Table 1. Hospital merger cases in Germany, 2005-2010

\begin{tabular}{|c|c|c|}
\hline Merging hospitals & Year & Conclusion by the BKA \\
\hline Rhön and Bad Neustadt/Mellrichstadt & 2005 & Prohibited and confirmed in court \\
\hline Rhön and Eisenhüttenstadt & 2005 & Prohibited \\
\hline Asklepios and LBK Hamburg & 2005 & $\begin{array}{l}\text { Cleared, subject to the condition } \\
\text { of selling one location }\end{array}$ \\
\hline Nürnberg and Nürnberger Land & 2005 & Cleared \\
\hline Humaine and Fresenius & 2006 & Cleared \\
\hline Greifswald and Wolgast & 2006 & Prohibited $^{\mathrm{a}}$ \\
\hline Hannover and Wunstorf & 2007 & Cleared \\
\hline LBK Hamburg and Mariabilf & 2007 & Prohibited \\
\hline Rhön and Wesermarsch Klinik & 2008 & Cleared \\
\hline Freiburg and Bad Krozingen & 2009 & Cleared \\
\hline Nordhessen and Werra-Meißner-Kreis & 2009 & Prohibited \\
\hline
\end{tabular}

BKA $=$ Bundeskartellamt (Federal Cartel Office).

${ }^{a}$ In January 2008, the Federal Minister of Economics and Technology (Bundesminister für Wirstschaft und Technologie) permitted the merger on appeal, arguing that, despite its likely anticompetitive effects, it served the public interest since one party involved was a small university hospital suffering from scale-related inefficiencies.

\subsection{Experiences with hospital merger control}

Until 2011 the BKA has examined more than 100 hospital merger cases, clearing most within one month. Some, however, have been challenged (Bangard, 2007; Denzel et al., 2010). Since 2000, an increasing number of public hospitals were sold to private hospital chains driven mainly by public authorities' large budget deficits at the regional and municipal levels (Schulten, 2006). To ensure that hospital markets are organised as competitively as possible, the BKA applies the GWB rather strictly in the industry. From 2005 to 2010, five proposed hospital mergers were prohibited and one was cleared, subject to the condition that the merging parties sell one hospital location to a third party (Table 1).

The first BKA-prohibited hospital merger was in March 2005, after which the Federal Court of Justice [Bundesgerichtshof (BGH)] in Germany confirmed the GWB to be fully applicable to the hospital industry (BGH, 2008). No social or hospital law precludes the GWB's merger control provisions to markets for hospital services. In addition, the court concluded that the objectives of antitrust law and health policy do not conflict with one another.

\subsection{Approach to defining geographic hospital markets}

The BKA defines the relevant product market as the market for acute hospital services, including general hospitals and specialised clinics but excluding rehabilitation and other nursing centres. To define geographic hospital markets, the BKA uses a backward-looking approach based on the analysis of patient flow 
data. Rather than 'merely theoretical' hospital alternatives, the BKA argues that only 'practical' alternatives should be taken into account when defining the relevant geographic market (BKA, 2005a). By considering where patients have gone in the past for hospital services, the BKA infers which hospitals are substitutable from the patient's perspective. Generally, the BKA's approach to defining geographic hospital markets consists of two steps. First, the catchment areas of each hospital - starting with an area of $\sim 100 \times 120 \mathrm{~km}$ around the merging hospitals - are identified. The second, decisive step is to analyse the travel behaviour of patients.

Because the BKA approach to defining geographic hospital markets also relies on patient flow data, at first sight it seems closely related to the widely criticised E-H test. There are, however, two fundamental differences. First, when computing the export of hospital services, the BKA does not aggregate patient inflows to all hospitals within the hypothesised geographic market, but rather takes into account only patients travelling to the merging hospitals. Overstatement of the true size of geographic hospital markets - an important pitfall when analysing patient flow data - is therefore less likely. This is illustrated by the hypothetical case described in Box 2.

The second difference between the E-H test and the BKA's approach is that the latter is based on pragmatic considerations, including case-specific characteristics, rather than fixed thresholds. From the BKA's decisions, it follows that generally only areas from which a substantial percentage of patients travel to one of the merging hospitals are potentially included in the relevant market (Kallfass and Kuchinke, 2006). That is, mutual patient flows between both areas need to be substantial. ${ }^{11}$ Whereas the E-H test tends to include gradually more areas simply to meet the $90 \%$ or $75 \%$ import and export thresholds, the BKA only includes or excludes neighbouring areas after assessing their specific competitive situation.

The BKA's approach is unlikely to suffer from the 'silent majority fallacy': it recognises that the presence of travelling patients does not necessarily restrain hospitals from behaving anti-competitively. More specifically, although the E-H test incorrectly assumes that the presence of some travelling patients disciplines hospitals from exercising market power over the silent majority of nontravelling patients, the BKA assumes that only the presence of many travelling patients disciplines hospitals from exercising market power over the then silent minority of non-travelling patients. Despite its use of patient flow data to define geographic hospital markets, the BKA is therefore not likely to overstate the true size of the relevant market. On the contrary and as argued by Badtke (2008), the BKA's approach may result in hospital markets that are too narrowly defined. Hence, the BKA seems keener on avoiding the risk of being too lenient (i.e. allowing hospital mergers that may restrict actual hospital competition)

11 The threshold for this is not specified by the BKA (Denzel et al., 2010). 
Box 2. Illustration of Bundeskartellamt (BKA) approach vs Elzinga-Hogarty $(\mathrm{E}-\mathrm{H})$ test for defining geographic hospital markets

Consider a hypothesised geographic market, including three hospitals: two merging general hospitals $\mathrm{A}$ and $\mathrm{C}$ and one academic teaching hospital $\mathrm{B}$. The latter offers services highly differentiated from those offered by the other hospitals. Therefore, $70 \%$ of its 10,000 patients come from outside the hypothesised market, whereas the percentage of travelling patients for the other hospitals is only $10 \%$ of 5000 patients each. Under these hypothetical circumstances, it is easy to see how the BKA approach defines a different relevant geographic market than the $\mathrm{E}-\mathrm{H}$ test. The relevant statistic for the export of hospital services in the E-H test ['little out from inside' (LOFI)] is $40 \%$, being total patient inflow in the area $(7000+2 \times 500)$ as percentage of the total number of patients treated there $(20,000)$. This is higher than the threshold generally used for a 'weak' market. Hence, according to the E-H test the geographic market is too narrowly defined and its boundary should therefore be expanded. When the BKA computes the export of hospital services from the hypothesised geographic market, however, it only analyses the inflow of patients to the merging hospitals (A and C) rather than all three hospitals in the region. The percentage of exports is then $10 \%$, being patient inflow of both hospitals $(1000)$ as percentage of the number of patients treated by those hospitals $(10,000)$. This low percentage implies that the hypothesised geographic market should not be enlarged. As the highly differentiated product provided by hospital B induces travel for specific reasons, it would indeed be incorrect to conclude that hospitals $A$ and $C$ face competition from hospitals elsewhere. Note that if hospital B provided the same services as the other two hospitals while still attracting many patients from outside the hypothesised market (e.g. due to its high quality), the BKA approach could result in a market that is too narrowly defined.

rather than being too stringent (i.e. prohibiting hospital mergers that may not restrict actual hospital competition).

\subsection{Landmark case: Rhön-Klinikum AG/Bad Neustadt/Mellrichstadt}

In August 2004, Rhön-Klinikum AG, one of the leading private hospital groups in Germany, notified the BKA of its plan to acquire two public hospitals: one in Bad Neustadt ( $\sim 150 \mathrm{~km}$ east of Frankfurt am Main) and one in Mellrichstadt ( $\sim 15 \mathrm{~km}$ north of Bad Neustadt). At the time, Rhön-Klinikum operated 30 hospitals nationwide with an aggregate turnover of more than $€ 1000$ million; the BKA therefore decided to substantively assess the likely competitive effects of the proposed acquisition and concluded that the transaction would further strengthen Rhön-Klinikum's dominant position in the two markets concerned 
(BKA, 2005a). It is a landmark case because it was the first time the BKA prohibited a hospital merger and prevailed in court. ${ }^{12}$

\subsubsection{Geographic market definition}

By applying its two-step approach to defining geographic hospital markets, the BKA in this particular case concluded that (i) for most general hospitals, the vast majority of patients live nearby, implying that the export of hospital services from one area to another is low and (ii) most patients do not travel to more distant alternatives, implying that the import of hospital services from one area to another is also low. The BKA agreed that some patients are willing to travel; however, as they do so for particular reasons (e.g. specialised care), such behaviour was not expected to significantly affect hospital competition. As a result, two different geographic markets were defined that were both rather small: the Bad Neustadt/Bad Kissingen market and the Meiningen market. With these areas, the merger would have increased Rhön-Klinikum's market shares to $\sim 65 \%$ and $60 \%$, respectively (BKA, 2005a).

\subsubsection{Court decisions}

Following its decision to prohibit the hospital merger, the BKA twice prevailed in court. First, in April 2007, the Düsseldorf Higher Regional Court (Oberlandesgericht Düsseldorf) confirmed the approach used by the BKA for defining the relevant geographic market. The court stated that patient flow data provide reliable information about the substitutability of hospitals and the BKA could therefore use it for market definition. As hospitals' substitutability crucially depends on the distance patients are willing to travel, the court argued that it was appropriate to analyse where patients had gone in the past. The conclusion was that areas only belong to the same geographic market when mutual patient flows between them are 'substantial' (OGD, 2007). Second, an appeal on points of law by the merging hospitals was dismissed in January 2008 by the Federal Court of Justice, making the BKA's prohibition of the merger final. The highest court in Germany confirmed that the use of patient flow data is appropriate when defining the relevant geographic market in hospital merger cases. The BKA's approach to defining geographic markets was deemed 'legally tenable' (BGH, 2008). In its decision, the court also argued that patients' potential hospital alternatives should not be taken into account if they had not actually visited them in the past, implying that most value is attached to revealed preference data, but emphasising that potential alternatives were not meaningless. They were called 'particularly useful' when assessing the factors that may limit or extend the merged hospital's market power.

12 Shortly after this decision, the BKA also prohibited Rhön-Klinikum AG from acquiring the municipal hospital in Eisenhüttenstadt, concluding that the merger would strengthen Rhön's already dominant position in the the Frankfurt/Oder region, because it already owned the principal hospital in that area (BKA, 2005b). 


\section{Hospital merger control in the Netherlands}

\subsection{Competition Act and guidelines for antitrust enforcement in bealth care}

The Dutch Competition Act [Mededingingswet (Mw)], implemented in 1998 and amended in 2004, is enforced by the Netherlands Competition Authority [Nederlandse Mededingingsautoriteit (NMa)]. In addition to prohibiting cartels and abusively dominant positions, the $\mathrm{Mw}$ practises preventive merger control. The latter generally only applies to mergers between companies whose combined turnover has exceeded $€ 113$ million in the preceding calendar year, with at least $€ 30$ million realised in the Netherlands by at least two of the companies involved. Because geographic markets for health care tend to be small and the emerging competition in the Dutch healthcare system is fragile, as competition among providers has only gradually been introduced since 2005, thresholds for the healthcare industry were temporarily lowered in January 2008 to $€ 55$ million and $€ 10$ million, respectively. To prevent them from applying to mergers of companies whose healthcare services are but a small part of their business, a third threshold was added: for at least two of the companies involved, turnover from healthcare services alone must exceed $€ 5.5$ million. ${ }^{13}$

Qualifying merger proposals must be reported to the NMa before consummation for a general review. A merger requires a license when there is reason to assume that "a dominant position that appreciably restricts competition on the Dutch market or a part thereof could arise or be strengthened as a result of the said concentration" (Mw, Section 37.2). Upon license application, the NMa begins a more substantial assessment of the proposed merger, deciding to allow, prohibit or conditionally allow the merger based on its findings: "A license shall be refused if, as a result of the proposed concentration, effective competition on the Dutch market or a part thereof would be appreciably impeded, specifically as a result of the creation or strengthening of a dominant economic position" (Mw, Section 41.2). On the basis of supranational European guidelines, a dominant position is defined as "a position of one or more undertakings that enables them to prevent effective competition being maintained on the Dutch market or a part thereof, by giving them the power to behave to an appreciable extent independently of their competitors, their suppliers, their customers or end-users" ( $\mathrm{Mw}$, Section 1.i).

In 2002, the NMa issued their first guidelines for antitrust enforcement policy in markets for health care, updating them in 2007 and 2010, which include a section on preventive merger control. After explaining the procedures of the notification and licensing phases, they discuss how they assess a dominant position. Several elements are considered, including market shares and concentration levels,

13 The lowered thresholds are particularly relevant to nursing homes and home healthcare organisations, as mergers in these markets generally do not qualify for the general thresholds. 
Table 2. NMa's decisions in hospital merger cases in the Netherlands, 2004-2010

\begin{tabular}{|c|c|c|c|}
\hline Merging hospitals & Year & Decision 1st stage & $\begin{array}{l}\text { Decision } 2 \mathrm{nd} \\
\text { stage }\end{array}$ \\
\hline $\begin{array}{l}\text { Juliana Kinderziekenhuis/RKZ and Ziekenhuis } \\
\text { Leyenburg }\end{array}$ & 2004 & No license required & - \\
\hline Ziekenhuis Hilversum and Ziekenhuis Gooi-Noord & 2005 & License required & License issued \\
\hline Erasmus MC and Havenziekenhuis & 2005 & No license required & - \\
\hline Ziekenhuis Walcheren and & 2006 & License required & Application \\
\hline Oosterscheldeziekenhuizen & & & withdrawn \\
\hline Laurentius Ziekenhuis and St. Jans Gasthuis & 2007 & No license required & - \\
\hline Vlietland Ziekenhuis and MC Rijnmond Zuid & 2007 & No license required & - \\
\hline MC Alkmaar and Gemini Ziekenhuis & 2007 & No license required & - \\
\hline St. Lucas Ziekenhuis and Ziekenhuis Delfzicht & 2008 & No license required & - \\
\hline Ziekenhuis Walcheren and & 2008 & License required & License issued $^{\mathrm{a}}$ \\
\hline \multicolumn{4}{|l|}{ Oosterscheldeziekenhuizen } \\
\hline Bethesda Ziekenhuis and Scheperziekenhuis & 2009 & No license required & - \\
\hline Noorderbreedte and Ziekenhuis De Tjongerschans & 2010 & License required & License issued \\
\hline
\end{tabular}

$\mathrm{NMa}=$ Nederlandse Mededingingsautoriteit (Netherlands Competition Authority).

an March 2009, the NMa approved the merger to 'safeguard the quality of basic hospital care' in the central region of the sparsely populated province of Zeeland. To prevent the merged hospital from exercising market power, 'strict conditions' were imposed (NMa, 2009). The geographic market was not in dispute.

countervailing buyer power and the likelihood of entry (NMa, 2010). When assessing the likely competitive effects of a proposed hospital merger, the NMa takes into account the opinion of the Dutch Healthcare Authority [Nederlandse Zorgautoriteit $(\mathrm{NZa})]{ }^{14}$

\subsection{Experiences with hospital merger control}

Before 2004, the NMa did not assess proposed hospital mergers; they argued that hospitals were not able to compete because of supply and price regulation. In 2004, however, the NMa issued a position document in which it stated that institutional and regulatory changes in Dutch healthcare markets had created scope for competition (NMa, 2004a). Because providers of hospital services compete, the $\mathrm{Mw}$ applied to the hospital industry.

Until 2011, eleven hospital mergers have been assessed by the NMa (Table 2), ${ }^{15}$ seven of which did not require a license. In only four cases, a license was required. After the substantive assessment, three were cleared and one was withdrawn.

14 The NZa is an autonomous administrative agency under the Dutch Ministry of Health, Welfare and Sport that since 2006 is responsible for monitoring and regulating healthcare markets in the Netherlands.

15 Note that the same merger between Ziekenhuis Walcheren and Oosterscheldeziekenhuizen was reported to the NMa in both 2006 and 2008. 
No decision has therefore been challenged and, unlike the United States and Germany, no court decisions on hospital market definition have yet been made, implying no industry-specific case law.

\subsection{Landmark case: Ziekenhuis Hilversum - Ziekenhuis Gooi-Noord}

In April 2004, two neighbouring general hospitals (Hilversum and Gooi-Noord), located in the region between Amsterdam and Utrecht, notified the NMa about their plan to merge. After the first general assessment in the notification phase, the NMa in July 2004 concluded that a license was required for the proposed merger as it could restrict actual competition in the Dutch market for hospital care. Following the hospitals' application for a license, the NMa in December 2004 started a more specific and substantial assessment of the concentration. As the first proposed hospital merger subject to a substantive assessment by the NMa, it therefore created a precedent and constituted a landmark case.

\subsubsection{Geographic market definition}

On the basis of market research and case law from other countries, the NMa identified two separate product markets: one for inpatient and one for outpatient general hospital care. In the first general assessment during the notification phase, the E-H test was used to define the geographic market, which turned out to be rather small, despite the E-H tendency to overstate true market size. The NMa therefore concluded that patients currently preferred hospitals close to their homes and that, as a consequence, the proposed merger would substantially lessen competition (NMa, 2004b). At the same time, they declared the E-H test static and concluded that further research on where patients would be willing to go when given incentive to do so was therefore necessary.

The in-depth analysis carried out in the licensing phase had three major findings. First, general practitioners (GPs), ${ }^{16}$ other hospitals and health insurers were interviewed. GPs and other hospitals expected patients to bypass the merged hospitals if they exercised market power, but health insurers did not expect patients' willingness to travel to be high. Second, patients' stated preferences were investigated by a conjoint analysis, ${ }^{17}$ the result of which was that the vast majority of patients would travel to other hospitals if the nearest hospital increased its price or lowered its quality. This indicated that the relevant geographic market was larger than that initially assumed. Third, econometric simulations to examine patients' willingness to travel to alternative hospitals

16 In the Netherlands, patients require a referral from their GP to visit a hospital for non-emergency care.

17 Conjoint analysis deals with situations in which a patient has to choose among hospital options that simultaneously vary among two or more attributes. The hypothetical problem is how to trade off the possibility that hospital $\mathrm{X}$ is better than hospital $\mathrm{Y}$ on attribute $\mathrm{A}$ but worse than hospital $\mathrm{Y}$ on attribute $\mathrm{B}$ and so on. The goal of conjoint analysis is to determine how much each hospital attribute contributes to patients' preferences. 
using actual hospital choices (revealed preferences) within a logit demand model confirmed the initial assumption that the geographic market was rather small.

Therefore, unfortunately for the $\mathrm{NMa}$, the research findings in this merger case were ambiguous. On the basis of the geographic market defined on the stated preference data, the merger should be allowed; when defined on revealed preference data, the merger should be prohibited. Confronted with these contradictory findings, the NMa concluded that, although greater value should be attached to revealed preferences, patients' willingness to travel could increase in the near future because of the increasing availability of consumer information about quality differences within the Dutch hospital sector. According to the NMa it was therefore "less evident that greater weight should be given to the revealed preferences in the assessment of the present case" (NMa, 2005). As a result, the NMa decided there were 'insufficient grounds' for defining a smaller geographical market.

\subsubsection{Final decision}

In June 2005, the NMa decided to clear the merger because there was "insufficient evidence to deem it plausible that a dominant position will arise or be strengthened as a result of the proposed merger on the markets for clinical and non-clinical general hospital care" (NMa, 2005). The conclusion implied that greater weight was given to consumers' stated preferences - even though they admitted that what people say they will do is often not the same as what they will do should the hypothetical situation become reality. In addition, the expectation that Dutch patients' willingness to travel was likely to increase because increased transparency was not based on empirical evidence and therefore (highly) speculative. All in all, this decision shows that, contrary to its German counterpart, the Dutch competition authority is keen on avoiding the risk of being too stringent (i.e. prohibiting hospital mergers that may not restrict actual hospital competition) rather than being too lenient (i.e. allowing hospital mergers that may restrict actual hospital competition). Future analysis of post-merger market performance results should reveal whether the NMa erred in this case. ${ }^{18}$

\section{Discussion}

To safeguard competition in market-oriented healthcare systems, preventive merger control is critical. For hospital services, however, its major problem is to define the relevant geographic market. Evidence from the United States shows

18 Besides negative quality effects, mergers may also result in higher prices. In the Netherlands, hospitals and health insurers are allowed to freely negotiate prices for about $70 \%$ of the hospital services in 2012, starting from $10 \%$ in 2005. As mergers reduce the number of hospital alternatives, they lower insurers' bargaining clout and may therefore eliminate the emerging price competition. In a first retrospective analysis of this particular hospital merger, Kemp and Severijnen (2010) indeed found a statistically significant price increase for hip surgery of which prices are freely negotiable since 2005 . As their analysis included only one procedure, however, no general conclusions about the effects of the merger could be drawn. 
that the method used for this has a huge impact on the outcome of hospital merger control. Here, we examined how geographic hospital markets are defined in two European countries with competitive hospital industries: Germany and the Netherlands. For each country, we discussed an important landmark case in which the definition of the relevant geographic market played a decisive role.

As a general observation, we argue that defining geographic hospital markets in Germany and the Netherlands seems less complicated than in the United States because of the absence of managed care. In such a setting, typical in the United States, the key issue for geographic market definition is which hospitals are important for managed care organisations to include in their networks. In a setting where hospitals compete directly for patients by non-price factors only - as is the case in Germany and the Netherlands because in both countries out-of-pocket payments, if present at all, do not differ across hospital alternatives - hospitals' substitutability crucially depends on patients' willingness to travel. ${ }^{19}$ When used properly, commonly available patient flow data is then useful for defining geographic hospital markets. ${ }^{20}$ Exploring innovative approaches, ${ }^{21}$ empirical analyses of where patients have gone in the past can be used to substantiate any conclusions about other hospitals as feasible alternatives for the merging hospitals (Varkevisser et al., 2010). In addition, as seen from the FTC's Hospital Merger Retrospectives Project (Farrell et al., 2009), ex post analysis of consummated hospital mergers can provide important information about ex ante geographic market definition for future cases (Ashenfelter et al., 2011).

An important conclusion is that, despite the fact that within the EU national antitrust laws are to a large extent based on the same legal principles, enforcement policies in German and Dutch hospital markets are notably different. Germany's BKA follows a thorough and pragmatic two-step approach to analyse patient flow data for geographic market definition, which is more likely

19 Although hospital prices in the Netherlands may differ across hospitals, these differences do not matter to patients because the mandatory annual deductible (220 in 2012) is far below the price of any hospital service charged by any hospital.

20 Despite the gradual introduction of managed competition in the Netherlands, hospitals there also compete directly for patients through non-price factors. So far, Dutch health insurers have been quite reluctant to selectively contract with hospitals. However, patient flow data would become less useful for defining Dutch hospital markets if insurer-hospital negotiations over network participation and composition increased. Then health insurers, rather than individual patients, will be the relevant hospital customers from an antitrust perspective. In such an environment, the option demand approach would be more appropriate for defining hospital markets (Varkevisser et al., 2008).

21 In recent years, several new approaches to defining geographic hospital markets have been suggested in the health economics literature, including time elasticity, competitor share and option demand. These new approaches provide strong evidence that hospitals may possess far more market power than previously acknowledged (Dranove and Sfekas, 2009). New methods have actually been used in a recent hospital merger case. In FTC and State of Ohio vs ProMedica Health System, the court - which so far has sided with the FTC - cited in its written opinion the 'willingness-to-pay' analysis brought forward by the plaintiff (see http://www.ftc.gov/os/caselist/1010167/110329promedicafindings.pdf). 
to result in hospital markets that are too narrowly defined. In the first Dutch hospital merger case in which definition of the geographic market played a decisive role, the NMa adopted an effects analysis that is more likely to approve mergers. That is, although the analysis of patient flow data pointed to the presence of a rather small market in which the proposed hospital merger would substantially reduce competition, the NMa used stated preference data to argue that the relevant market might change substantially in the near future in the case of readily available quality information. Hence, we find that different methods of defining geographic hospital markets result in much more stringent hospital merger control in Germany than in the Netherlands. Given the uncertainties in defining appropriate hospital markets, the German competition authority seems to be inclined to avoid the risk of being too permissive, whereas the opposite holds for the Dutch situation. As a result, in Germany, since 2005, five proposed hospital mergers have been prohibited by the BKA and only one was cleared, subject to the condition that the merging parties sell one hospital location to a third party. By contrast, all proposed hospital mergers in the Netherlands have been allowed thus far.

Empirical studies have provided clear evidence that hospital mergers may have serious anticompetitive effects, while claimed cost savings are most often not achieved (Vogt and Town, 2006; Weil, 2010). Therefore, the reduction in social welfare caused by allowing a hospital merger that restricts hospital competition is likely to be greater than the reduction in social welfare caused by blocking a hospital merger that does not restrict hospital competition. This implies that for society the risk of being too permissive with regard to hospital mergers may be larger than the risk of being too stringent. ${ }^{22}$ This asymmetry is even more relevant in light of the following two facts. First, the unscrambling of consummated hospital mergers is rather problematic. If there is real clinical and medical integration, then divestiture is even less likely to be a good remedy, as it then has a greater risk of unforeseen costs and failures. This makes pre-merger enforcement decisions in this industry more important. Second, ex post identification of the exercise of market power is difficult in most European countries where hospitals typically compete for patients by quality rather than price. In hospital markets with quality competition, post merger antitrust enforcement may therefore not be an effective safety net. Hence, in view of the uncertainties about the true size of geographic hospital markets, antitrust enforcement agencies may do better to risk being too restrictive when assessing proposed hospital mergers rather than being too permissive. This may be particularly true for the emerging hospital markets in Germany and in the Netherlands, given their long-standing tradition of collective bargaining and concerted practice, and the substantial entry barriers.

22 Note that such an asymmetry has also been identified for other industries, for example, Lévêque (2006). 
Impact of geographic market definition on hospital merger control 379

\section{Acknowledgement}

We thank seminar participants at the Netherlands Competition Authority (NMA, 13 January 2009), the German Bundeskartellamt (BKA, 9 May 2008) and Erasmus University Rotterdam (4 December 2008) for helpful comments.

\section{References}

Ashenfelter, O., D. Hosken, M. Vita and M. Weinberg (2011), 'Retrospective analysis of hospital merger cases', International Journal of the Economics of Business, 18(1): $5-16$.

Bangard, A. (2007), 'Krankenhausfusionskontrolle' ('Hospital merger control'), Zeitschrift für Wettbewerbsrecht (Journal of Competition Law), 2: 183-238.

Badtke, F. (2008), 'Die Anwendbarkeit der deutschen und europäischen Fusionskontrolle auf Zusammenschlüsse von Krankenhäusern' ('The applicability of German and European merger control to hospital mergers'), Dissertation, Humboldt-Universität, Berlin.

Bundesgerichtshof (BGH) (2008), Beschluss KVR26/07 - Kreiskrankenhaus Bad Neustadt, Bonn: Bundesgerichtshof.

Bundeskartellamt (BKA) (2005a), Beschluss B10-123/04 - Rhön-Klinikum AG - Landkreis Rhön-Grabfeld, Bonn: Bundeskartellamt.

BKA (2005b), Beschluss B10-109/04 - Rhön-Klinikum AG - Krankenhaus Eisenhüttenstadt GmbH - Stadt Eisenhüttenstadt, Bonn: Bundeskartellamt.

Campbell, T. (2007), 'Defending hospital mergers after the FTC's unorthodox challenge to the Evanston Northwestern - Highland Park transaction', Annals of Health Law, 16(2): 213-239.

Capps, C. S., D. Dranove, S. Greenstein and M. Satterthwaite (2002), 'Antitrust policy and hospital mergers: recommendations for a new approach', Antitrust Bulletin, 47(4): $677-714$.

Carlton, D. W. (2007), 'Does antitrust need to be modernized?', Journal of Economic Perspectives, 21(3): 155-176.

Commonwealth Fund (2010), International Profiles of Health Care Systems: Australia, Canada, Denmark, England, France, Germany, Italy, the Netherlands, New Zealand, Norway, Sweden, Switzerland, and the United States, New York/Washington, DC.

Conners, J. R. (2003), 'A critical misdiagnosis: how courts underestimate the anticompetitive implications of hospital mergers', California Law Review, 91: 543-578.

Danger, K. L. and H. E. Frech (2001), 'Critical thinking about "critical loss” in antitrust', Antitrust Bulletin, 46(2): 339-355.

Denzel, S., S. Krolop and D. M. Dürr (2010), 'Auswirkungen der Fusionskontrolle auf den deutschen Krankenhaussektor' ('The impact of hospital merger control on the German hospital market'), Zeitschrift fur öffentliche and gemeinwirtschaftliche Unternehmen (Journal for Public and Nonprofit Services), 38: 53-71.

Dranove, D. and A. Sfekas (2009), 'The revolution in health care antitrust: new methods and provocative implications', Milbank Quarterly, 87(3): 607-632.

Elzinga, K. G. and A. W. Swisher (2011), 'Limits of the Elzinga-Hogarty test in hospital merger: the Evanston case', International Journal of the Economics of Business, 18(1): 133-146.

European Commission (EC) (2007), Case No COMP/M.4367 - APW/APSA/Nordic Capitall Capio, Brussels: European Commission. 
Farrell, J., P. A. Pautler and M. G. Vita (2009), 'Economics at the FTC: retrospective merger analysis with a focus on hospitals', Review of Industrial Organization, 35(4): 369-385.

Federal Trade Commission (FTC) (2004), In the Matter of Evanston Northwestern Healthcare Corporation: Complaint, Washington, DC: The Federal Trade Commission, Docket No. 9315.

FTC (2005), In the Matter of Evanston Northwestern Healthcare Corporation: Initial Decision, Washington, DC: The Federal Trade Commission, Docket No. 9315.

FTC (2007), In the Matter of Evanston Northwestern Healthcare Corporation: Opinion of the Commission, Washington, DC: The Federal Trade Commission, Docket No. 9315.

Gaynor, M. and W. B. Vogt (2000), 'Antitrust and Competition in Health Care Markets', in A. J. Cuyler and J. P. Newhouse (eds), Handbook of Health Economics, vol. I, Amsterdam: Elsevier Science, 1405-1487.

Greaney, T. L. (2002), 'Whither antitrust? The uncertain future of competition law in health care', Health Affairs, 21(2): 185-196.

Harris, B. C. and D. A. Argue (2006), 'FTC v. Evanston Northwestern: a change from traditional hospital merger analysis?', Antitrust, Spring: 34-40.

Heyer, K. (2006), 'Welfare standards and merger analysis: why not the best?', Competition Policy International, 2(2): 29-54.

Kallfass, H. H. and B. A. Kuchinke (2006), 'Die räumliche Marktabgrenzung bei Zusammenschlüssen von Krankenhäusern in den USA und in Deutschland: eine wettbewerbsökonomische Analyse' ('Geographic market definition in hospital merger cases in the United States and in Germany: an antitrust analysis'), Diskussionspapier Nr. 52, Institut für Volkswirtschaftslehre, Technische Universität Ilmenau.

Kemp, R. and A. Severijnen (2010), Price effects of Dutch hospital mergers: an ex post assessment of hip surgery, NMa Working Papers No. 2, The Hague: Netherlands Competition Authority.

Lévêque, F. (2006), 'Antitrust enforcement in the electricity and gas industries: problems and solutions for the EU', The Electricity Journal, 19(5): 27-34.

Lisac, M., L. Reimers, K. D. Henke and S. Schlette (2010), 'Access and choice - competition under the roof of solidarity in German health care: an analysis of health policy reforms since 2004', Health Economics, Policy and Law, 5(1): 31-52.

Motta, M. (2004), Competition Policy: Theory and Practice, Cambridge: Cambridge University Press.

Nederlandse Mededingingsautoriteit (NMa) (2004a), Visiedocument ziekenhuiszorg ('Position Document Hospital Care'), Den Haag: Nederlandse Mededingingsautoriteit.

NMa (2004b), Besluit betreffende zaak 3897/Ziekenhuis Hilversum - Ziekenhuis GooiNoord: meldingsfase, Den Haag: Nederlandse Mededingingsautoriteit.

NMa (2005), Besluit betreffende zaak 3897/Ziekenhuis Hilversum - Ziekenhuis Gooi-Noord: vergunningfase, Den Haag: Nederlandse Mededingingsautoriteit, (English translation available at www.nmanet.nl/engels/home/Decisions/2005/3897BVC_engels.asp).

NMa (2009), NMa Imposes Strict Conditions on Hospital Merger, The Hague: press release.

NMa (2010), Richtsnoeren voor de zorgsector ('Guidelines for the Health Care Industry'), Den Haag: Nederlandse Mededingingsautoriteit.

Oberlandesgericht Düsseldorf (OGD) (2007), Beschluss VI-Kart 6/05 (V), Düsseldorf: Oberlandesgericht Düsseldorf.

Pittman, R. (2007), 'Consumer surplus as the appropriate standard for antitrust enforcement', Competition Policy International, 3(2): 205-224. 
Richman, B. D. (2007), 'Antitrust and nonprofit hospital mergers: a return to basics', University of Pennsylvania Law Review, 156: 121-150.

Schut, F. T. and W. P. M. M van de Ven (2011), 'Effects of purchaser competition in the Dutch health system: is the glass half full or half empty?', Health Economics, Policy and Law, 6(1): 109-123.

Schulten, T. (2006), Liberalisation, Privatisation and Regulation in the German Healthcare Sector/Hospitals, Düsseldorf: Wirtschafts- und Sozialwissenschaftliches Institut (WSI), Hans-Böckler-Stiftung.

Simpson, J. (2003), 'Geographic markets in hospital mergers: a case study', International Journal of the Economics of Business, 10(3): 291-303.

Varkevisser, M., C. S. Capps and F. T. Schut (2008), 'Defining hospital markets for antitrust enforcement: new approaches and their applicability to The Netherlands', Health Economics, Policy and Law, 3(1): 7-29.

Varkevisser, M., S. A. van der Geest and F. T. Schut (2010), 'Assessing hospital competition when prices don't matter to patients: the use of time-elasticities', International Journal of Health Care Finance and Economics, 10(1): 43-60.

Vita, M. G. and S. Sacher (2001), 'The competitive effects of not-for-profit hospital mergers: a case study', Journal of Industrial Economics, 49(1): 63-84.

Vogt, W. B. and R. Town (2006), How has Hospital Consolidation Affected the Price and Quality of Hospital Care?, Research Synthesis Report No. 9, Robert Wood Johnson Foundation, Princeton, NJ.

Weil, T. P. (2010), 'Hospital mergers: a panacea?', Journal of Health Services Research \& Policy, 15(4): 251-253. 